\title{
Social Cohesion and City Green Space: Revisiting the Power of Volunteering
}

\author{
Viniece Jennings
}

Former Employee of USDA Forest Service, 320 Green Street, Athens, GA 30602, USA; vjennings026@gmail.com; Tel.: +1-404-953-5124

Received: 4 August 2019; Accepted: 29 August 2019; Published: 20 September 2019

check for updates

\begin{abstract}
Urban green spaces can facilitate positive social interactions in numerous ways. These interactions may lead to the development of social cohesion among city dwellers. This article provides a viewpoint on the potential role that the presence of green space and volunteering can play in the construct of social cohesion. Specifically, the article focuses on one aspect of social cohesion, volunteerism, as a way to illustrate the immense potential of social cohesion to link health with place and the planet.
\end{abstract}

Keywords: social cohesion; green space; parks; volunteering

\section{Introduction}

Social cohesion is often described as the social connections, trust, and/or overall solidarity among residents [1]. A recent literature review identified factors such as social relations and communal activities as essential aspects of social cohesion [2]; however, the definition of social cohesion can vary. By providing places where people can potentially bond with others and engage in a range of social and communal activities, urban parks and green spaces can facilitate civic activities [3-5]. Scholars describe how social cohesion is within the social determinants of health and linked to positive health outcomes such as increased physical activity, lower levels of stress, and improved subjective well-being [6,7]. Although social cohesion is a major pathway influencing the relationship between green space and health [7], it also represents an area in need of additional research [6,7], especially in cities [8]. However, measuring social cohesion has been challenging.

Volunteer activity is linked with reciprocity and trust and considered one of the most common indicators of social cohesion $[9,10]$. Volunteerism involves activities where people freely give to individuals or a cause in ways that are beneficial to societies overall [11]. Volunteering is considered a pro-social behavior that links people to the production and exchange of goods and services; it can further build on a moral effort to benefit a cause to which the participant is affiliated [12]. Being involved in volunteer efforts may improve one's perception of themselves and their surroundings, as well as provide access to beneficial resources and contacts [13]. Volunteering may also relate to social ties, which are a key predictor of place attachment [14] and collective action.

Different types of volunteering may relate to the presence of parks and other recreational spaces. Environmental agencies have long relied on volunteers to support their management activities $[15,16]$, and many agencies are developing new approaches to engage both volunteers and partner organizations [17]. In many cases, these efforts can motivate an inspired workforce of stewards dedicated to restoring and maintaining parks, thereby enhancing community resilience [18]. In addition to nature-based settings like parks, volunteering is also common in other recreational contexts, such as sports settings (baseball and soccer fields, basketball courts). For many, sports volunteering provides a mechanism for building social networks, social cohesion, and social capital $[19,20]$. In one case, Kay and Bradbury investigated the role of volunteering in sports-related activities in 
the development of social capital among youth, finding that respondents reported greater social connectedness and other benefits as a result of their participation in sports volunteering [21].

Insights on the benefits of volunteering across the parks and recreation sector can contribute to our understanding of the broader link between green space and social cohesion. Specifically, proportions of volunteering can be used as an indicator for social cohesion $[9,10]$ and trust. The recognition that organized sport activities are key drivers of park use [22,23] suggests amenities such as sports fields and recreational centers may also influence civic engagement [24]. A similar pathway can be hypothesized between volunteering in green spaces and broader forms of civic engagement.

While the motivations to volunteer can vary [12], scholars suggest that these motivations can often be grouped into one of four categories: egoism, increasing one's own welfare; altruism, increasing the welfare of others; collectivism, increasing the welfare of a group one belongs to; and principlism, upholding personal values [25]. Regardless of motivations, volunteer activities represent a promising avenue to facilitate social interactions [26] and measure social cohesion [9]. Importantly, volunteering builds a sense of place attachment with the settings in which people volunteer [13]. Some research has found that more green spaces are correlated with greater social bonds between volunteers and their neighborhood organizations [27], which could be explained by the strong place attachment that greener neighborhoods elicit.

Scholars generally analyze social interactions at the neighborhood scale [28], but the examination of how green space influences volunteering and social cohesion should also be performed a macro-level (e.g., city/metropolitan scale) scale. As more outside entities (e.g., private foundations) are funding park and recreational facilities, cities are often competing with each other for these and other sources [29]. Cities also represent an important and understudied scale of analysis for studies on the provision of parks and recreation and on the social environment $[8,30]$. Such insights can bridge the knowledge gap between urban green spaces and social interactions [8,31]. Examination of this topic is particularly timely, given declines in urban social relations, gaps in the academic literature, and interest in social interactions from practitioners $[8,32,33]$. We hope to reimagine ways that urban green spaces (e.g., parks and gardens) and recreational spaces can partner to bring about the best in people and the places they value.

\section{Conclusions}

Social cohesion is a key construct that links urban green spaces and health. As previous authors describe how volunteer activity is considered an indicator of social cohesion, it represents a potential pathway in the relationship between green space and health that should be explored. By studying the social pathways that urban green spaces connect people with place and service to others, we are better positioned to understand its multifaceted link to human health.

Funding: This research received no external funding.

Acknowledgments: The author acknowledges the editorial contributions of Matthew Browning, Lincoln Larson, and Alessandro Rigolon.

Conflicts of Interest: The author declares no conflict of interest.

\section{References}

1. Comstock, N.; Dickinson, L.M.; Marshall, J.A.; Soobader, M.-J.; Turbin, M.S.; Buchenau, M.; Litt, J.S. Neighborhood attachment and its correlates: Exploring neighborhood conditions, collective efficacy, and gardening. J. Environ. Psychol. 2010, 30, 435-442. [CrossRef]

2. Schiefer, D.; van der Noll, J. The Essentials of Social Cohesion: A Literature Review. Soc. Indic. Res. 2017, 132, 1-25. [CrossRef]

3. Westphal, L. Urban Greening and Social Benefits: A Study of Empowerment Outcomes. J. Arboric 2003, 29, 137-147. 
4. Tidball,K.G.; Krasny, M.E. From risk to resilience: What role for community greening and civic ecology in cities. In Social Learning towards a More Sustainable World; Wageningen Academic: Wageningen, The Netherlands, 2007; pp. 149-164.

5. Shanahan, D.F.; Bush, R.; Gaston, K.J.; Lin, B.B.; Dean, J.; Barber, E.; Fuller, R.A. Health benefits from nature experiences depend on dose. Sci. Rep. 2016, 6, 28551. [CrossRef] [PubMed]

6. Jennings, V.; Bamkole, O. The Relationship between Social Cohesion and Urban Green Space: An Avenue for Health Promotion. Int. J. Environ. Res. Public Health 2019, 16, 452. [CrossRef] [PubMed]

7. Hartig, T.; Mitchell, R.; de Vries, S.; Frumkin, H. Nature and Health. Ann. Rev. Public Health 2014, 35, $207-228$. [CrossRef] [PubMed]

8. Jennings, V.; Larson, L.; Yun, J. Advancing Sustainability through Urban Green Space: Cultural Ecosystem Services, Equity, and Social Determinants of Health. Int. J. Environ. Res. Public Health 2016, 13, 196. [CrossRef] [PubMed]

9. Smith, L.M.; Case, J.L.; Smith, H.M.; Harwell, L.C.; Summers, J.K. Relating ecoystem services to domains of human well-being: Foundation for a U.S. index. Ecol. Indic. 2013, 28, 79-90. [CrossRef]

10. Rajulton, F.; Ravanera, Z.R.; Beaujot, R. Measuring social cohesion: An experiment using the Canadian national survey of giving, volunteering, and participating. Soc. Indic. Res. 2007, 80, 461-492. [CrossRef]

11. Snyder, M.; Omoto, A.M. Volunteerism: Social issues perspectives and social policy implications. Soc. Issues Policy Rev. 2008, 2, 1-36. [CrossRef]

12. Parker, S.R. Volunteering-Altruism, markets, causes and leisure. World Leis. Recreat. 1997, 39, 4-5. [CrossRef]

13. Midlarsky, E. Helping as coping. In Pro-social Behavior; Clark, M., Ed.; Sage: Newbury Park, CA, USA, 1991.

14. Lewicka, M. Place attachment: How far have we come in the last 40 years? J. Environ. Psychol. 2011, 31, 207-230. [CrossRef]

15. Stebbins, R.A.; Graham, M. Volunteering as Leisure/Leisure as Volunteering: An International Assessment; Centre for Agriculture and Bioscience International (CABI): Wallingford, UK, 2004.

16. Holifield, R.; Williams, K.C. Urban Parks, Environmental Justice, and Voluntarism: The Distribution of Friends of the Parks Groups in Milwaukee County. Environ. Justice 2014, 7, 70-76. [CrossRef]

17. Barnes, M.L.; Sharpe, E.K. Looking beyond traditional volunteer management: A case study of an alternative approach to volunteer engagement in parks and recreation. Volunt. Int. J. Volunt. Nonprofit Organ. 2009, 20, 169. [CrossRef]

18. Dresner, M.; Handelman, C.; Braun, S.; Rollwagen-Bollens, G. Environmental identity, pro-environmental behaviors, and civic engagement of volunteer stewards in Portland area parks. Environ. Educ. Res. 2015, 21, 991-1010. [CrossRef]

19. Cuskelly, G. Volunteering in community sport organizations: Implications for social capital. In Sport and Social Capital; Elsevier: Amsterdam, The Netherlands, 2008; pp. 187-206.

20. Harvey, J.; Lévesque, M.; Donnelly, P. Sport Volunteerism and Social Capital. Sociol. Sport J. 2007, 24, $206-223$. [CrossRef]

21. Kay, T.; Bradbury, S. Youth sport volunteering: Developing social capital? Sport Educ. Soc. 2009, 14, 121-140. [CrossRef]

22. Loukaitou-Sideris, A.; Sideris, A. What Brings Children to the Park? Analysis and Measurement of the Variables Affecting Children's Use of Parks. J. Am. Plan. Assoc. 2009, 76, 89-107. [CrossRef]

23. Cohen, D.A.; Han, B.; Nagel, C.J.; Harnik, P.; McKenzie, T.L.; Evenson, K.R.; Marsh, T.; Williamson, S.; Vaughan, C.; Katta, S. The first national study of neighborhood parks: Implications for physical activity. Am. J. Prev. Med. 2016, 51, 419-426. [CrossRef]

24. Henderson, K.A.; Neff, L.J.; Sharpe, P.A.; Greaney, M.L.; Royce, S.W.; Ainsworth, B.E. "It takes a village" to promote physical activity: The potential for public park and recreation departments. J. Park Recreat. Adm. 2001, 19, 23-41.

25. Batson, C.D.; Ahmad, N.; Tsang, J.-A. Four motives for community involvement. J. Soc. Issues 2002, 58, 429-445. [CrossRef]

26. Moen, P.; Dempster-McClain, D.; Williams, M., Jr. Successful Aging: A Life-Course Perspective on Women's Multiple Roles and Health. Am. J. Sociol. 1992, 97, 1612-1638. [CrossRef] 
27. Romolini, M.; Grove, J.M.; Locke, D.H. Assessing and comparing relationships between urban environmental stewardship networks and land cover in Baltimore and Seattle. Landsc. Urban Plan. 2013, 120, 190-207. [CrossRef]

28. Forrest, R.; Kearns, A. Social Cohesion, Social Capital and the Neighbourhood. Urban Stud. 2001, 38, 2125-2143. [CrossRef]

29. Rigolon, A.; Browning, M.; Jennings, V. Inequities in the quality of urban park systems: An environmental justice investigation of cities in the United States. Landsc. Urban Plan. 2018, 178, 156-169. [CrossRef]

30. Browning, M.; Rigolon, A. Do Income, Race and Ethnicity, and Sprawl Influence the Greenspace-Human Health Link in City-Level Analyses? Findings from 496 Cities in the United States. Int. J. Environ. Res. Public Health 2018, 15, 1541. [CrossRef]

31. Jennings, V.; Browning, M.H.E.M.; Rigolon, A. Cultural Ecosystem Services Meet Broader Frameworks in Public Health. In Urban Green Spaces; Springer: Cham, Switzerland, 2019; pp. 31-46.

32. Jennings, V.; Baptiste, K.A.; Osborne Jelks, N.; Skeete, R. Urban Green Space and the Pursuit of Health Equity in Parts of the United States. Int. J. Environ. Res. Public Health 2017, 14, 1432. [CrossRef]

33. Levasseur, M.; Cohen, A.A.; Dubois, M.-F.; Généreux, M.; Richard, L.; Therrien, F.-H.; Payette, H. Environmental factors associated with social participation of older adults living in metropolitan, urban, and rural areas: The NuAge study. Am. J. Public Health 2015, 105, 1718-1725. [CrossRef]

(C) 2019 by the author. Licensee MDPI, Basel, Switzerland. This article is an open access article distributed under the terms and conditions of the Creative Commons Attribution (CC BY) license (http://creativecommons.org/licenses/by/4.0/). 